\begin{tabular}{l|l|l} 
J & Jurnal Kependidikan Dasar & $\begin{array}{l}\text { volume : } 4 \\
\text { Nomor }: 2 \\
\text { Tahun }: 2019\end{array}$
\end{tabular}

\title{
Supervisi Akademik Kepala Sekolah dalam Meningkatkan Proses Pembelajaran Pendidikan Agama Islam di Madrasah Ibtidaiyah Nurul Huda Candisari Windusari Magelang
}

\author{
Muh Banjari, Achmad Hasanudin \\ Program Pascasarjana IAIN Salatiga \\ muhbanjari4@gmail.com, ahasanudin02@gmail.com
}

\begin{abstract}
This study aims to determine the methods, applications, inhibiting factors and supporting academic supervision of principals in improving the learning process of PAI. This study uses a phenomenological qualitative approach. The technique of data collection through documentation and interviews. While the data analysis of this study uses qualitative, inductive. The results of the study concluded that first, the academic supervision of principals used a collaborative approach. The supervision technique used uses two techniques, namely individual and group techniques. Individual techniques include: class visits, observations and individual meetings. Group techniques by holding teacher meetings and training to improve teacher competency. Second, the application of academic supervision is applied to all teachers. Conducted at the beginning of the new school year, every month on a scheduled and unscheduled basis. Third, inhibiting factors include: (a) the time of implementation is not in accordance with the schedule, (b) the health factor of the teacher and supervisor, (c) the social factors of the teacher supervised by the age of the supervisor. Supporting factors include: (a) the teacher's openness factor, (b) the principal can control, guide and develop the skills of the teacher, (c) the principal is motivated to worship to improve the quality of faithful and devoted human resources.
\end{abstract}

Keywords: Academic Supervision, Principal, Islamic Education Learning Process

\section{Abstrak}

Penelitian ini bertujuan untuk mengetahui metode, penerapan, faktor penghambat dan pendukung supervisi akademik kepala sekolah dalam meningkatkan proses pembelajaran PAI. Penelitian ini menggunakan metode pendekatan kualitatif jenis fenomenologi. Tenik pengambilan data melalui dokumentasi dan wawancara. Sedangkan analisis data penelitian ini menggunakan kualitatif yang bersifat induktif. Hasil penelitian menyimpulkan bahwa pertama, Supervisi akademik kepala sekolah menggunakan metode pendekatan kolaboratif. Teknik supervisi yang digunakan, menggunakan dua 
teknik yaitu teknik individu dan kelompok. Teknik individu meliputi: kujungan kelas, observasi dan pertemuan individu. Teknik kelompok dengan mengadakan rapat dan pelatihan guru untuk meningkatkan kompetensi guru. Kedua, Penerapan supervisi akademik diterapkan kepada semua guru. Dilaksanakan pada awal tahun ajaran baru, setiap bulan secara terjadwal dan tidak terjadwal (insidental). Ketiga, faktor penghambat meliputi: (a) waktu pelaksanaannya tidak sesuai dengan jadwal, (b) faktor kesehatan guru dan supervisor, (c) faktor sosial guru yang disupervisi usianya lebih tua dari supervisor. Faktor pendukung meliputi: (a) faktor keterbukaan guru, (b) kepala sekolah dapat mengontrol, membimbing dan mengembangkan keterampilan guru, (c) kepala sekolah termotivasi untuk beribadah meningkatkan kualitas sumber daya manusia yang beriman dan bertaqwa.

Kata kunci: Supervisi Akademik, Kepala Sekolah, Proses Pembelajaran Pendidikan Agama Islam

\section{PENDAHULUAN}

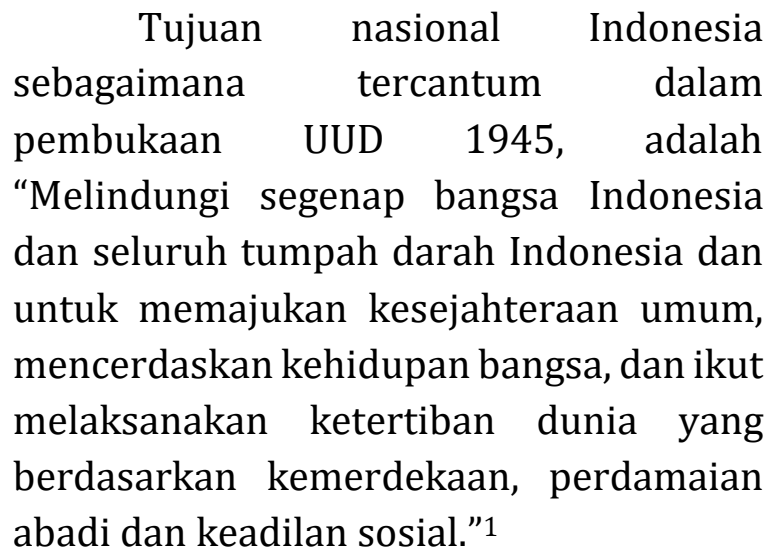

Tugas guru dalam proses pembelajaran dan pendidikannya, esensi pembelajaranya harus memiliki tiga sasaran hasil belajar, yaitu: tumbuhnya pengetahuan baru, tumbuhnya kemampuan baru, tumbuhnya perubahan baru. ${ }^{2}$ Kepemimpinan di lembaga sekolah yang diperankan kepala sekolah mempengaruhi orang lain seperti guru dan personel sekolah untuk mencapai tujuan yang diinginkan. Tujuan yang akan

\footnotetext{
${ }^{1}$ Undang-Undang Dasar Negara RI Tahun 1945.

2 Fathurrohman and Suryana, Supervisi Pendidikan Dalam Pengembangan Proses Pengajaran.
}

tercapai jika kepala sekolah mau dan mampu membangun komitmen dan bekerja keras untuk menjadikan sekolah yang dipimpinnya menjadi sekolah yang berkualitas dan menjadi terbaik di daerahnya. ${ }^{3}$

Kepala sekolah sebagai pemimpin berperan untuk memberikan batuan kepada guru dalam menghadapi kesulitan dalam proses pembelajaran, dengan memberikan petunjuk dan pengarahan kepada guru-guru sebagai mana firman Allah swt dalam surat As Sajdah ayat 24:

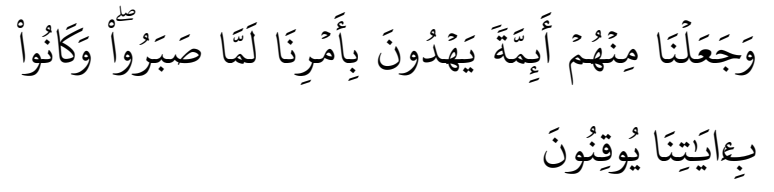

Artinya:

"Dan Kami jadikan diantara mereka itu pemimpin-pemimpin yang memberi petunjuk dengan perintah Kami selama mereka sabar."4

\footnotetext{
${ }^{3}$ Sagala, Supervisi Pembelajaran Dalam Profesi Pendidikan.

${ }^{4} \mathrm{RI}$, Terjemahnya, Al Qur"an Dan.
} 
Syaiful mengungkapkan pengawasan penting sekali dilakukan kepala sekolah untuk menjamin bahwa layanan pendidikan atau layanan belajar terus menerus membaik. ${ }^{5}$ Dalam proses supervisi, supervisor dapat berperan sebagai sumber informasi, sumber ide, sumber petunjuk dalam berbagai hal dalam rangka peningkatan kemampuan profesional guru. Supervisi sebagai evaluasi, untuk mengetahui kemampuan guru yang akan dibina perlu dilakukan evaluasi sehingga program supervisi cocok dengan kebutuhan guru. ${ }^{6}$

Supervisi akademik adalah serangkaian kegiatan membantu guru mengembangkan kemampuannya mengelola proses pembelajaran demi pencapaian tujuan pembelajaran. ${ }^{7}$ Oleh karena itu, kegiatan supervisi akademik dipandang perlu untuk meningkatkan kompetensi profesional guru termasuk guru PAI dalam proses pembelajaran.

Guru Pendidikan Agama Islam merupakan salah satu guru di Sekolah menengah tingkat pertama yang mempunyai peran penting dalam pembentukan akhlak dan karakter anak. Guru PAI mempunyai pengawas dari Kementrian Agama, namun hal ini tidak maksimal sehingga perlu peran Kepala Sekolah dalam memberikan supervisi.

Suharsimi ${ }^{8}$ mengemukakan bahwa dalam kenyataannya kepala sekolah belum dapat melaksanakan supervisi dengan baik dengan alasan beban kerja kepala sekolah yang terlalu berat serta

\footnotetext{
${ }^{5}$ Sagala, Supervisi Pembelajaran Dalam Profesi Pendidikan, 132.

${ }^{6}$ Kompri, Manajemen Pendidikan.
}

latar belakang pendidikan yang kurang sesuai dengan bidang studi yang disupervisi. Sehingga tujuan untuk membina dan membimbing guru masih belum sempurna serta guru kurang memahami makna dari pentingnya supervisi yang dilakukan oleh kepala sekolah.

Upaya peningkatan proses pembelajaran Pendidikan Agama Islam di Madrasah Ibtidaiyah bukan masalah yang sederhana, tetapi memerlukan penanganan yang multidimensi dengan melibatkan berbagai pihak yang terkait. Untuk mencapai hal itu, kepala sekolah melakukan berbagai upaya diantaranya adalah dengan meningkatkan kemampuan supervisi akademik kepala sekolah.

\section{METODE PENELITIAN}

Penelitian ini dilaksanakan pada tangggal 11 Januari sapai dengan tanggal 20 februari dengan obyek penelitian Kepala sekolah dan guru PAI di MI Nurul Huda Candisari. Dalam penelitian menggunakan metode pendekatan kualitatif jenis fenomenologi yaitu pemahaman pada filosofi dan psikologi dari pengalaman hidup manusia. Metode pengumpulan data yaitu dengan wawancara dan dokumentasi. Metode analisis data menggunakan analisis data kualitatif bersifat induktif yaitu analisis berdasarkan data yang diperoleh, selanjutkan dikembangkan pola hubungan tertentu atau menjadi hipotesis.

\footnotetext{
${ }^{7}$ Dharma, Metode Dan Tehnik Supervisi, 9.

${ }^{8}$ Arikunto, Dasar-Dasar Supervisi, 4.
} 


\section{HASIL DAN PEMBAHASAN}

\section{Pengertian Supervisi Akademik}

Glickman dalam Darma, mendefinisikan supervisi akademik adalah serangkaian kegiatan membantu guru mengembangkan kemampuannya mengelola proses pembelajaran demi pencapaian tujuan pembelajaran. ${ }^{9}$ supervisi akademik adalah bantuan profesional kepada guru, melalui siklus perencanaan yang sistematis, pengamatan yang cermat, dan umpan balik yang objektif dan segera. ${ }^{10}$

Kepala sekolah adalah seorang fungsional guru yang diberi tugas untuk memimpin suatu sekolah dimana diselenggarakan proses belajar mengajar, atau tempat dimana terjadi interaksi antara guru yang memberi pelajaran dan murid yang menerima pelajaran. ${ }^{11}$

Pembelajaran adalah proses interaksi antara peserta didik dengan lingkunganya yang membangun interaksi secara penuh. ${ }^{12}$ Pendidikan Agama Islam Menurut Abdurrahman al Nahwawi dalam Abdullah, pendidikan islam merupakan suatu proses penataan individual dan sosial yang menjadikan seseorang tunduk dan taat sekaligus menerapkan Islam secara sempurna dalam kehidupan individu dan masyarakat. ${ }^{13}$

Perilaku profesional akan lebih diwujudkan dalam diri guru, apabila

\footnotetext{
${ }^{9}$ Dharma, Metode Dan Tehnik Supervisi, 9.

${ }^{10}$ Mulyasa, Manajemen Dan Kepemimpinan Kepala Sekolah, 213.

${ }^{11}$ Makawimbang, Kepemimpinan Pendidikan Yang Bermutu.

${ }^{12}$ Sagala, Supervisi Pembelajaran Dalam Profesi Pendidikan.

${ }^{13}$ Suharto and Idi, Revitalisasi Pendidikan Islam, 47.
}

institusi tempat ia bekerja memberi perhatian lebih banyak pada pembinaan, pembentukan, dan pengembangan sikap profesional. ${ }^{14}$ Oleh karena itu kepala sekolah harus menguasai konsep supervisi akademik. Supervisi merupakan aktivitas yang harus dilakukan oleh seorang pemimpin berkaitan dengan peran kepemimpinan yang diembannya dalam rangka menjaga kualitas produk yang dihasilkan lembaga. ${ }^{15}$ Kepala sekolah dalam melaksanakan supervisi harus memiliki tujuan. Menurut Glickman dalam Donni Juni Priansa dan Rismi Somad, Secara umum, tujuan supervisi akademik adalah membantu guru untuk mengembangkan kemampuannya dalam mencapai tujuan pembelajaran yang direncanakan bagi peserta didiknya. ${ }^{16}$ Tujuan pembelajaran adalah harapan perubahan yang dicapai oleh peserta didikdari adanya proses pembelajaran. ${ }^{17}$

Dalam pelaksanaan supervisi akademik kepala sekolah harus mampu menguasai semua aspek supervisi akademik. Keberhasilan pembelajaran guru di pengaruhi oleh kepala sekolah sebagai seorang pemimpin dalam melakukan supervisi dan pembinaan terhadap guru agar tujuan proses pembelajaran dapat berjalan dengan baik.

Me

\footnotetext{
${ }^{14}$ Karwati and Priansa, Kinerja Dan Profesionalisme Kepala Sekolah.

${ }^{15}$ Arikunto and Yuliana, Manajemen Pendidikan, 380.

${ }^{16}$ Priansa and Somad, Manajemen Supervisi Dan Kepemimpinan Kepala Sekolah, 108.

${ }^{17}$ Faturrohman, Belajar Dan Pembelajaran Membantu Meningkatkan Mutu Pembelajaran Sesuai Standar Nasional, 12.
} 


\section{tode Supervisi Akademik Kepala Sekolah}

Kompetensi supervisi akademik kepala sekolah merupakan aspek yang paling strategis karena bersentuhan langsung dengan kopetensi guru. Prilaku siswa sangat dipengaruhi oleh prilaku guru, prilaku guru dalam pembelajaran dipengaruhi oleh prilaku pengawas. ${ }^{18}$ Untuk itu perlu pemilihan metode dan teknik supervisi yang tepat. Berdasarkan temuan yang ada di lapangan metode supervisi kepala sekolah. Sebagaimana yang disampaikan oleh kepala MI Nurul Huda Candisari bapak SP dalam wawancara bahwa: "Metode pendekatan yang kami gunakan menggunakan metode pendekatan secara kolaboratif, memberikan masukan dan bimbingan kepada guru terkait. Kemudian kami menggunakan teknik supervisi individu dan kelompok. Tenik supervisi individu kami menggunakan teknik kujungan kelas, observasi dan pertemuan individu. Teknik supervisi kelompok kami mengadakan rapat tahunan dan rapat bulanan, selain itu kami juga mengadakan pelatihan guru untuk meningkatkan kompetensi guru".19

$$
\text { Metode pendekatan yang }
$$
digunakan dalam supervisi akademik yang dilakukan kepala sekolah MI Nurul Huda Candisari yaitu:

1. Metode pendekatan kolaboratif

Pendekatan kolaboratif adalah cara pendekatan yang memadukan cara pendekatan direktif dan nondirektif menjadi pendekatan

\footnotetext{
18 Masaong, Supervisi Pembelajaran Dan

Pengembangan Kapasitas Guru, 17.

19 SP, "Data Wawancara Dengan SP."

${ }^{20}$ Maunah, Supervisi Pendidikan Islam, 190.
}

baru. ${ }^{20}$ Pada pendekatan ini baik supervisor maupun guru bersamasama, bersepakat untuk menetapkan struktur, proses dan kriteria dalam melaksanakan proses percakapan terhadap masalah yang dihadapi guru. Perilaku supervisor adalah sebagai berikut: menyajikan, menjelaskan, mendengarkan, memecahkan masalah, dan negosiasi. Pendekatan ini biasa digunakan oleh supervisor untuk mensupervisi kepada guru yang profesional. ${ }^{21}$ Di MI Nurul Huda Candisari guru PAI semuanya sudah S1, sudah lama mengajarnya. Sehingga dalam pelaksanaan supervisi saling mempengarui, bertanggung jawab, saling berperan dalam pemecahan masalah dilakukan secara bersama.

2. Teknik supervisi akademik

Berdasrkan data hasil wawancara dengan kepala sekolah maupun guru PAI teknik supervisi akademik mengunakan dua teknik supervisi yaitu teknik supervisi individu dan teknik supervisi kelompok.

a. Teknik supervisi individu

Teknik supervisi individual adalah supervisi yang diberikan kepada guru tertentu yang mempunyai masalah khusus dan bersifat perorangan. ${ }^{22}$ Teknik individu yang digunakan di MI Nurul Huda Candisari yaitu:

1). Kunjungan kelas

Dalam kegiatan ini kepala sekolah masuk kedalam ruangan

\footnotetext{
${ }^{21}$ Snae, Modul Kepala Sekolah Belajar Supervisi Akademik, 85.

${ }^{22}$ Sawithi, Supervisi Akademik.
} 
kelas dengan membawa intrumen penilaian supervisi. Untuk melihat kesiapan dalam pelaksanan proses pembelajaran. Seperti memeriksa kelengkapan admistrasi pembelajaran RRP, jurnal mengajar, absensi, instrumen penilaian. Selain administrasi kepala sekolah juga mengamati jalanya proses pembelajaran untuk melihat apa kekurangan atau kelemahan yang sekiranya perlu diperbaiki. Kemudian kepala sekolah bersama guru mengadakan perjanjian untuk membicarakan hasil-hasil observasi, dan tahap tindak lanjut.

2). Observasi kelas

Dalam pelaksanaan observasi kelas yang dilakukan kepala sekolah MI Nurul Huda Candisari dilakukan dengan tidak terjadwal. Sewaktuwaktu kepala sekolah lansung datang ke kelas untuk melihat guru PAI yang sedang mengajar. Seperti yang diungkapkan oleh kepala sekolah bapak SP dalam wawancaranya:"Observasi yang saya lakukan tidak terjadwal, sewaktu-waktu saya langsung datang melihat lihat Guru PAI yang sedang mengajar bagaimana mengajarnya atau metode yang di gunakan dalam mengajar. (insidental)"23

Semua guru PAI yang ada di MI Nurul Huda Candisari dituntut untuk selalu siap dan profesional dalam melaksanakan proses pembelajaran.

3). Pertemuan Individu

Dalam pertemuan individu kepala sekolah MI Nurul Huda Candisari memanggil guru yang mempunyai permasalahan dalam proses pembelajaran di tempat yang sudah di sepakati. Dalam pertemuan ini kepala sekolah dengan guru, bersamasama berdiskusi mencari solusi jalan keluar terhadap masalah yang dihadapi guru tersebut. Selain itu kepala sekolah memberikan bimbingan dan memotivasi agar ada perbaikan dalam proses pembelajaran.

b. Teknik supervisi kelompok

Teknik supervisi kelompok adalah satu cara melaksanakan program supervisi yang ditujukan pada dua orang atau lebih, memiliki masalah atau kebutuhan atau kelemahankelemahan yang sama dikumpulkan menjadi satu/bersama-sama. ${ }^{24}$ Teknik supervisi kelompok yang digunakan di oleh kepala sekolah MI Nurul Huda Candisari adalah:

1). Mengadakan rapat

${ }^{23}$ SP, "Data Wawancara Dengan SP."

${ }^{24}$ Sawithi, Supervisi Akademik, 30. 
Rapat merupakan salah satu kegiatan supervisi kelompak yang dilakukan oleh kepala sekolah untuk memberikan bimbingan dan pemecahan masalah yang ada dalam pelaksanaan proses pembelajaran. Dalam rapat ini semua permasalahan yang berkaitan dalam pembelajaran dimunculkan kemudian dibahas secara bersama untuk memberikan penyelesaian atau jalan keluar terhadap masalah yang dihadapi oleh guru tersebut. Didalam rapat hubungan antara guru dengan kepala sekolah sangat harmonis karena adanya keterbukaan dan saling menghormati satu dengan yang lainya.

2). Mengadakan pelatihan

Mengadakan pelatihan merupakan salah satu cara dari kepala sekolah MI Nurul Huda Candisari membantu guru dalam mengembangkan kompetensi tertentu yang dianggap masih rendah. Tujuan dari mengikut sertakan guru dalam pelatihan ini adalah untuk meningkatkan kopetensi guru agar lebih baik sehingga dalam pengolahan proses pembelajaran akan meningkat. Secara otomatis apabila proses pembelajaran meningkat akan mempengaruhi dari hasil pembelajaran.

\section{Perencanaan Supervisi Akademik Kepala Sekolah}

Perencanaan program supervisi akademik adalah penyusunan dokumen perencanaan, pemantauan serangkaian kegiatan membantu guru

\footnotetext{
${ }^{25}$ Prasojo and Budiyono, Supervisi Pendidikan.
}

mengembangkan kemampuannya mengelola proses pembelajaran untuk mencapai tujuan pembelajaran. ${ }^{25}$ Kepala MI Nurul Huda Candisari, menyusun perencanaan supervisi akademik di awal tahun pelajaran baru. Perencanaan ini diwujudkan dalam program supervisi akademik. Supervisi ini lebih ditekankan kepada semua guru mata pelajaran seperti guru Pendidikan Agama Islam. Program supervisi akademik ini sangat penting bagi kepala sekolah sebagaimana disampaikan bapak SP dalam wawancara bahwa: "Perencanaan supervisi akademik kami buat dalam bentuk program supervisi. Program supervisi akademik itu sangat penting, karena sebagai acuan dalam melaksanakan supervisi. Dalam pembuatan perencanaan saya selalu koordinasi dengan semua guru pada waktu rapat kerja (raker) awal tahun. Dan dalam pelaksanaan supervisi saya berkoordinasi dengan bagian akademik. Program supervisi ini juga saya sosialisasikan kepada semua guru dan kariyawan pada waktu rapat tahun ajaran baru. Hal ini dimaksudkan agar guru dan karyawan juga memahami maksud dan tujuan program supervisi akademik ini."26 Dalam menyusun rencana supervisi akademik kepala sekolah berkoordinasi dengan semua guru, bersama-sama menentukan hal-hal yang berkaitan dalam pelaksanaan supervisi yaitu: Menentukan masalah yang akan di supervisi, Menentukan tujuan supervisi akademik, Indikator yang akan di supervisi, Waktu pelaksanaan supervisi, Tempat pelaksanaan supervisi,

${ }^{26}$ SP, "Data Wawancara Dengan SP." 
Menentukan metode dan teknik supervisi, Penilain dan intrumen. Setelah rencana pelaksanaan supervisi dibuat kemudian disosialisasikan oleh kepala sekolah kepada semua guru pada rapat tahun ajaran baru. Dengan tujuan agar semua guru mengetahui jaduwal kunjungan, memahami maksud tujuan pelaksanaan program supervisi akademik ini, tentu guru dengan senang mempersiapkan terkait pembelajaran yang akan dilaksanakan. Guru dan kepala sekolah memiliki persepsi yang sama dan saling tanggung jawab.

Kepala sekolah MI Nurul Huda Cadisari merencanakan pelaksanaan supervisi akademik terhadap guru PAI setiap awal tahun ajaran baru dan setiap bulan hal ini dilakukan untuk melihat perkembangan dan perubahan yang dilakukan guru dalam proses pembelajaran.

\section{Pelaksanaan Supervisi Akademik Kepala Sekolah}

Berdasarkan temuan di lapangan bahwa pelaksanaan supervisi akademik kepala sekolah MI Nurul Huda Candisari dilaksanakan setiap tahun ajaran baru setiap bulan dan diterapkan kepada semua guru. Seperti disampaikan oleh kepala sekolah MI Nurul Huda Candisari bapak SP dalam wawancara:"Supervisi akademik yang ada di sekolahan kami, penerapanya adalah pada awal tahun ajaran baru (raker) kami sampaikan programprogram supervisi kepada semua guru termasuk guru PAI, kemudian setiap bulan tanggal sembilan kami melaksanakan rapat, tentunya membahas temuan masalah yang menunjang pembelajaran, kemudian di bahas bersama-sama pendekatan dan rencana tindak lanjut". ${ }^{27}$

Penerapan supervisi akademik di MI Nurul Huda Candisari diterapkan kepada semua guru. Menitik beratkan pada supervisi administrasi dan proses pembelajaran. Pelaksanaannya pada awal tahun ajaran baru dan setiap bulan. Pada tahun ajaran baru kepala sekolah menggunakan pendekatan kolaboratif dan teknik supervisi kelompok yaitu dengan mengadakan rapat dalam rapat kepala sekolah memberikan bimbingan kepada semua guru dalam penyusunan administrasi kelas seperti Prota, Promes, RRP, Silabus, intrumen penilain dan administrasi lainya yang menunjang proses pembelajaran serta penggunaan strategi pembelajaran.

Selain dilaksanakan pada awal tahun ajaran baru pelaksanaan supervisi juga dilaksanakan pada setiap bulan secara terjadwal maupun tidak terjadwal (insidental) dengan menggunakan metode pendekatan kolaboratif dan teknik kelompok maupun individu. Pada setiap bulan pelaksanaan supervisi akademik kepala sekolah pada tanggal lima dan tanggal sembilan dengan menggunakan teknik kelompok melalui rapat. Dalam rapat ini dibahas temuan-temuan permasalahan yang dihadapi oleh guru dalam proses pembelajaran, kemudian dibahas bersama-sama untuk mencari solusi jalan keluar terhadap permasalahan yang menunjang pembelajaran. Kepala sekolah memberikan bimbingan dan 
memberikan motivasi kepada guru dengan tujuan untuk menigkatkan kompetensi guru. Kepala sekolah juga menyampaikan rencana tidak lanjut terhadap permasalahan yang dihadapi guru dalam proses pembelajaran. Untuk meningkatkan kopentensi guru yang masih kurang kemampuannya, maka pihak sekolah mengikutsertakan pelatihan guru dalam meningkatkan kompetensi guru dalam pengelolaan proses pembelajaran.

Kepala sekolah melaksanakan supervisi akademik dengan menggunakan teknik individu. Dalam pelaksanaanya kepala sekolah mengunakan intrumen dan penilain supervisi. Tenik individu yang sering digunakan adalah kunjungan kelas, observasi kelas dan pertemuan idividu. Teknik yang paling efektif untuk mengamati guru adalah kunjungan kelas, karena kepala sekolah dapat secara langsung melihat kesiapan administrasi, metode, ketrampilan guru dalam mengajar, serta melihat guru dalam memotivasi siswa dalam belajar. Selain itu, kepala sekolah juga melakukan pengamatan terhadap guru yang sedang mengajar di luar kelas secara tidak terjadwal untuk mengamati proses pembelajaran. Apabila didalam pengamatan terdapat masalah guru yang dihadapi dalam pelaksanaan proses pembelajaran, maka guru tersebut di panggil untuk melakukan pertemuan individu untuk diberikan bimbingan, dan berdiskusi untuk mencari jalan keluarnya terhadap masalah yang dihadapi.

\section{Tindak Lanjut Supervisi Akademik Kepala Sekolah}

Tindak lanjut supervisi merupakan manfaat dari hasil supervisi. Berdasarkan temuan dilapangan hasil supervisi akademik yang dilakukan kepala sekolah itu sangat penting karena dapat ber pengaruh terhadap peningkatan proses pembelajaran. Program tindak lanjut yang diberikan oleh kepala sekolah pada guru PAI berupa pemantauan dan bimbingan secara terus menerus baik secara kelompok maupun secara individu. Hal ini seperti yang disampaikan oleh kepala MI Nurul Huda bapak SP dalam wawancara: "Program tindak lanjut yang kami lakukan adalah pemantauan, dan bimbingan baik secara kelompok maupun individu. Secara kelompok kami mengadakan rapat bulanan. Dalam rapat bulanan kami memberikan bimbingan, motivasi, dan penguatan kepada semua guru termasuk guru PAI. Kami juga mengadakan KKG, ataupun workshop tergantung permasalahan yang kami temukan di lapangan. Kemudian kalau secara individu yang kami lakukan adalah dengan memanggil guru yang bersangkutan semisal pada saat disupervisi ada guru yang belum menguasai kelas guru tersebut kami panggil guru yang bersangkutan, diberikan saran dan motivasi untuk belajar bagai mana caranya untuk menguasai kelas." 28

Hal yang terpenting dalam program tindak lanjut supervisi akademik kepala sekolah sasaranya adalah peningkatan proses pembelajaran. Dengan adanya tindak lanjut berupa 
pembinaan, pemantauan dan bimbingan yang berkelanjutan baik secara individu maupun kelompok, agar dapat memberikan solusi jalan keluar yang terbaik terhadap masalah dan kendala yang muncul dalam pembelajaran. Selain itu, guru dapat mengembangkan ketrampilan mengajarnya dengan ikut serta dalam pelatihan guru atau workshop dalam peningkatan ketrampilan pengelolaan proses pembelajaran PAI yang diharapkan dapat meningkat.

\section{Faktor Penghambat Pelaksanaan Supervisi Akademik Kepala Sekolah}

Setiap kegiatan pasti ada kendalanya salah satunya kendala adalah faktor penghambat dari supervisi akademik yang dilakuakan kepala sekolah di MI Nurul Huda Candisari adalah: pertama, waktu pelaksanaannya tidak sesuai dengan jadwal. Waktu yang telah dijadwalkan disetujui oleh kepala dan guru yang di supervisi ini berubah karena adanya kegiatan lain yang mendesak, seperti kepala sekolah tiba-tiba ada rapat mendadak ada rapat yang tidak boleh diwakilkan ke Kemenag, sehingga waktu pelaksanaanya harus undur. Kedua, Faktor kesehatan guru dan supervisor. Waktu yang telah dijadwalkan disetujui oleh kepala dan guru pada saat yang sama salah satu dari kepala atau guru sedang sakit sehingga dalam pelaksanaan supervisi tidak maksimal. Ketiga, faktor sosial. Guru yang disupervisi usianya lebih tua dari supervisor. Sehingga dalam pelaksanaanya kurang maksimal.

\section{Fakor Pendukung Pelaksanaan Supervisi Akademik}

Faktor pendukung pelaksanaan supervisi akademik menjadi sebuah kekuatan penyemangat, dan dorongongan untuk melaksanakan program supervisi yang dilakukan kepala sekolah. Dari keterangan hasil wawancara dengan kepala sekolah bapak SP faktor pendukung pelaksanaan supervisi akademik di MI Nurul Huda Candiasri yaitu: pertama faktor keterbukaan guru, guru sudah memahami bahwa supervisi adalah salah satu alat sebagai untuk peningkatan evaluasi proses pembelajaran. Kedua kepala sekolah dapat mengontrol, membimbing dan mengembangkan ketrampilan guru. Ketiga, kepala sekolah termotivasi karena untuk beribadah meningkatkan kualitas sumber daya manusia yang beriman dan bertaqwa.

\section{SIMPULAN}

Berdasarkan pembahasan tentang supervisi akademik kepala sekolah MI Nurul Huda Candisari dapat diambil kesimpulan sebagai berikut: Metode supervisi akademik yang digunakan kepala sekolah MI Nurul Huda menggunakan metode pendekatan kolaboratif yaitu pendekatan langsung dan tidak langsung. Teknik supervisi yang digunakan, menggunakan dua teknik yaitu teknik individu dan kelompok. Teknik individu meliputi: kunjungan kelas, observasi dan pertemuan individu. Teknik kelompok dengan mengadakan rapat dan pelatihan guru untuk meningkatkan kompetensi guru. 
Penerapan supervisi akademik di MI Nurul Huda Candisari diterapkan kepada semua guru. Pelaksanaannya pada awal tahun ajaran baru, dan setiap bulan secara terjadwal maupun tidak terjadwal (insidental) dengan menggunakan metode pendekatan kolaboratif dan teknik kelompok maupun individu.

Faktor penghambat dari supervisi akademik yang dilakuakan kepala sekolah di MI Nurul Huda Candisari Windusari Magelang adalah (a) waktu pelaksanaannya kadang-kadang tidak sesuai dengan jadwal, (b) faktor kesehatan guru dan supervisor, (c) Faktor sosial guru yang di supervisi lebih tua dari supervisor. Sedangkan faktor pendukungnya adalah (a) faktor keterbukaan guru, (b) kepala sekolah dapat mengontrol, membimbing dan mengembangkan ketrampilan guru, (c) kepala sekolah termotivasi karena untuk beribadah meningkatkan kualitas sumber daya manusia yang beriman dan bertaqwa.

\section{DAFTAR PUSTAKA}

Arikunto, Suharsimi. Dasar-Dasar Supervisi. Jakarta: Rineka Cipta, 2004. Arikunto, Suharsimi, and Lia Yuliana. Manajemen Pendidikan. Yogyakarta: Aditya Media, 2008.

Dharma, Surya. Metode Dan Tehnik Supervisi. Jakarta: Direktorat Tenaga Kependidikan Direktorat Jenderal Peningkatan Mutu Pendidik Dan Tenaga Kependidikan, 2008.

Fathurrohman, P, and AA Suryana. Supervisi Pendidikan Dalam Pengembangan Proses Pengajaran. Bandung: Refika Aditama, 2011. Faturrohman, Muhammad. Belajar Dan Pembelajaran Membantu
Meningkatkan Mutu Pembelajaran Sesuai Standar Nasional. Yogyakarta: Teras, 2012.

Karwati, Euis, and Donni Juni Priansa. Kinerja Dan Profesionalisme Kepala Sekolah. Bandung: Alfabeta, 2013.

Kompri. Manajemen Pendidikan. Bandung: Alfabeta, 2015.

Makawimbang, Jeri H. Kepemimpinan Pendidikan Yang Bermutu. Bandung: Alfabeta, 2012.

Masaong, Abd. Kadim. Supervisi Pembelajaran Dan Pengembangan Kapasitas Guru. Bandung: Alfabeta, 2013.

Maunah, Binti. Supervisi Pendidikan Islam. Yogyakarta: Teras, 2009.

Mulyasa, E. Manajemen Dan Kepemimpinan Kepala Sekolah. Jakarta: Bumi Aksara, 2013.

Prasojo, Lantip Diat, and Budiyono Budiyono. Supervisi Pendidikan. Yogyakarta: Gava Media, 2011.

Priansa, Donni Juni, and Rismi Somad. Manajemen Supervisi Dan Kepemimpinan Kepala Sekolah. Bandung: Alfabeta, 2014.

RI, Kementerian Agama. Terjemahnya, Al Qur"an Dan. Jakarta: Sinergi Pustaka Indonesia, 2012.

Sagala, Saiful. Supervisi Pembelajaran Dalam Profesi Pendidikan. Bandung: Alfabeta, 2002.

Sawithi, Ni Wayan. Supervisi Akademik. Jakarta: Direktorat Jenderal Guru dan Tenaga Kependidikan, 2016.

Snae, Yandri D. I. Modul Kepala Sekolah Belajar Supervisi Akademik. Jakarta: Direktorat Jenderal Guru dan Tenaga Kependidikan, 2016.

SP. "Data Wawancara Dengan SP." n.d. Suharto, Toto, and Abdullah Idi. Revitalisasi Pendidikan Islam. Yogyakarta: Tiara Wacana, 2006. Undang-Undang Dasar Negara RI Tahun 1945. Surakarta: Al Hikmah, 2002. 


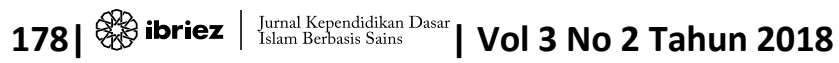

